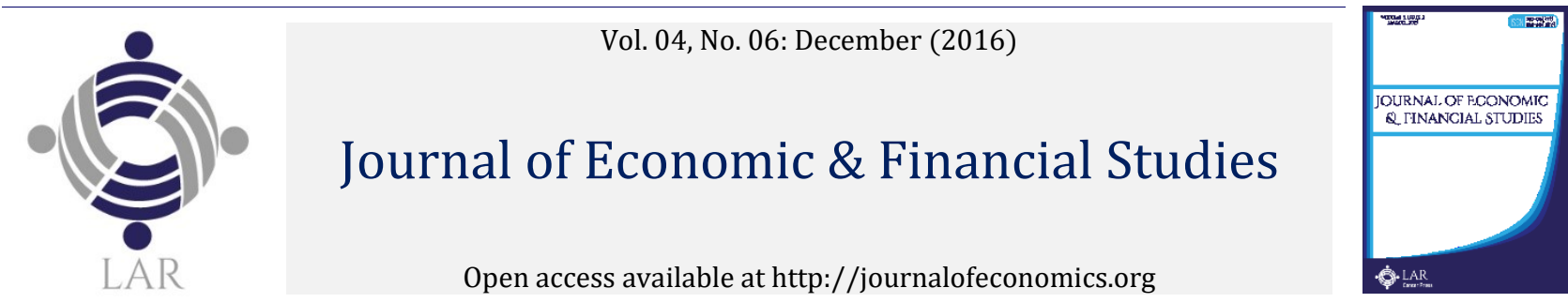

\title{
Macroeconomic conditions and unemployment in Nigeria
}

\author{
Augustine C. Osigwe ${ }^{a^{*}}$, Kenneth O. Ahambab \\ a Department of Economics and Development Studies, Federal University, Ikwo, Nigeria. \\ b Department of Economics and Development Studies, Federal University, Ikwo, Nigeria. E-mail: kendrys4jesus@yahoo.com \\ *Corresponding author's email address: onyi2amaka@yahoo.com
}

\section{A R T I C L E I N F O}

Received: 07-25-2016

Accepted: 09-20-2016

Available online: 03-01-2017

Keywords:

Macroeconomic variables;

Nigeria;

Unemployment.

JEL Classification :

$\mathrm{B} 22$; C22; C32.

\begin{abstract}
A B S T R A C T
We examine the effect of selected macroeconomic variables on unemployment rate in Nigeria using a battery cointegration tests. Results reveals a long run relation between unemployment rate (UNER) and chosen macroeconomic variables. The results of the vector error correction model (VECM) show that real GDP at lag 2 and current exchange rate (EXR) positively affect UNER. Moreover, UNER at lag 1, money supply (M2) at lag 2, EXR at lag 2, current lending rate (LR) and its first lag negatively affects UNER. These results are robust to the satisfaction of various diagnostic tests including residual normality assumption, correction for autocorrelation and white heteroskedasticity.
\end{abstract}

(C) 2016 The Authors. This is an open access article under the terms of the Creative Commons Attribution License 4.0, which allows use, distribution and reproduction in any medium, provided the original work is properly cited.

\section{$1.0 \quad$ Introduction}

Unemployment is one of the most critical problems facing Nigeria. The years of corruption, civil war, military rule, and mismanagement have hindered economic growth of the country. Nigeria is endowed with diverse and infinite resources, both human and material. However, years of negligence and adverse policies have led to the under-utilization of these resources. This is one of the primary causes of unemployment in Nigeria (EconomyWatch, 2010). Unemployment in Nigeria is a key problem both from economic and social view point. It contributes to low purchasing power which dovetails into less consumption and in turn to lower production and economic growth. Unemployment also has social consequences as it increases the rate of crime in the society. For instance, Asaju et al (2014) revealed that widespread poverty, youth restiveness, high rate of social vices and criminal activities are prevalent because of joblessness, and warned that if not controlled, apathy, cynicism and revolution might become the consequence. World Bank (2009) reports that 40 million (28.57\%) of Nigeria's employable people are unemployed. EconomyWatch (2010) documented that secondary-school graduates consist of the principal fraction of the unemployed in Nigeria, accounting for nearly $35 \%$ to $50 \%$. The rate of unemployment within the age group of 20 to 24 years is $40 \%$ and between 15 to 19 years it is $31 \%$.

The Nigeria's population pyramid captured in the CIA World Factbook (2014) indicated the following age structure 0-14 years: $43.2 \%$ (male 39,151,304/female 37,353,737), 15-24 years: $19.3 \%$ (male 17,486,117/ female 16,732,533), 25-54 years: $30.5 \%$ (male 27,697,644/female 26,285,816), 55-64 years: 3.9\% (male $3,393,631$ /female 3,571,301) and 65 years and over: 3.1\% (male 2,621,845/female 2,861,826). The massage deduced from these statistics is that the Nigerian population is children and youths dominating. A further implication of this is that a lot of youths who are able, ready and willing to work cannot find work in Nigeria. 
WDI (2014) put Nigeria youth unemployment at 13.7\% (\% of total labour force ages 15-24). The Coordinating Minister for the Economy and Minister of Finance, Dr. Ngozi Okonjo-Iweala while quoting official statistics from the National Bureau of Statistics (NBS) stated that no fewer than 5.3 million youths are jobless in Nigeria, while 1.8 million graduates enter the labour market every year (The Sun Newspaper of 24th November, 2014). However, this figure Minister of Finance seem somewhat a conservative estimate of the actual number of unemployed youths in the country, going by the previous statistics released by the NBS, which put the number of jobless Nigerians at 20.3 million. Despite repeated claims by the Federal Government that it has been able to create 1.6 million jobs this year, there is no demonstrable evidence that that figure has done much to reduce the rate of unemployment and poverty level in the country. Instead, the contrary appears to be the case.

Macroeconomic variables and unemployment rate nexus has been explored in different studies from various perspectives. The macroeconomic variables that enter any unemployment model are predicated by the combination of economic theory and the peculiarity of the economy the modeller is interested in. Early in the literature, Okun (1962) documented that economic growth and unemployment has negative relationship. The relationship between economic growth, unemployment and inflation based on traditional macro model is derived by the combination of Okun's law and Philips curve. Perman and Tavera (2007) noted that such relationship is a significant indicator of interdependence of output and labour movement in long run to capture the effect of higher unemployment.

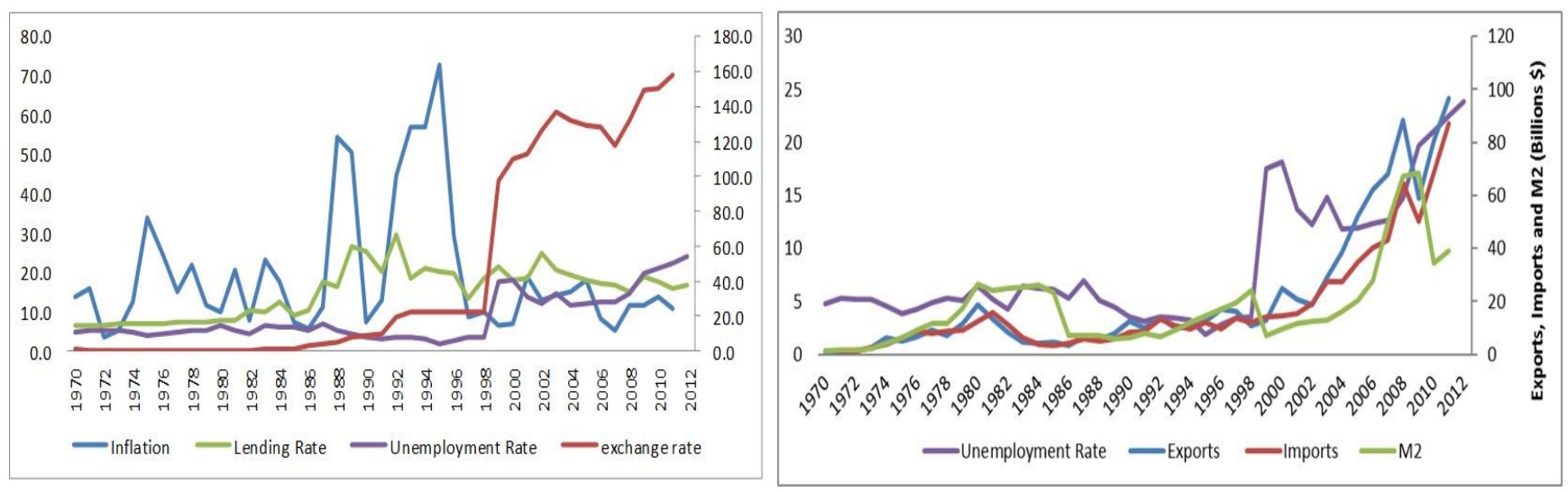

Source: Authors initiative with underlying data obtained from CBN (2014)

Figure 1: Trends in some selected macroeconomic variables and unemployment rates Nigeria

The remainder of this paper is structured in the following way. Section 2 presents the trends in some selected macroeconomic variables and unemployment rates Nigeria. Section 3 centres on literature review whereas section 4 briefly describes the theoretical framework and Methodology adopted. Section five presents and discusses the empirical results while section six concludes the study.

\subsection{Literature review}

Numerous empirical studies such as Cascio (2001) for 11 European countries, Orphanides and Williams (2002), Djivre and Ribon (2003) for Israel, and Ravn and Simonelli (2006) for the US, have investigated the relationship between monetary policy shocks and total unemployment. On the whole, these studies found that tight monetary policy increased unemployment. On the other hand, Agenor and Aizenman (1999) theoretically examined the effects of fiscal policies on output, wages and employment within a small open economy using the general equilibrium framework. They argued that expansionary fiscal policies increased unemployment. Alexius and Holmlund (2007) discovered that monetary policy had more persistent effects on unemployment than the fiscal policy and foreign demand in Sweden. Their results indicated that 30 per cent of the fluctuations in unemployment were caused by shocks to monetary policy during 1980 to 2005 .

Lynch and Hyclak (1984) and Ewing, Levernier and Malikin (2002) evaluated the effect of output deviations on unemployment rate for different age, gender and race groups of the United States. They discovered that the effects of output deviations are different on each of the different subgroups age, gender and race. Further, Blackley (1991), Freeman (2000), Izraeli and Murphy (2003) and Bisping and Patron (2005) showed that output and unemployment relationship differs among demographic groups within and between regions in the United States. Paci, Pigliaru and Pugno (2001) also analyzed the existing patterns of unemployment across western European regions. Within a three-sector model framework (agriculture, industry and services) they assessed whether sectoral dynamics help explaining the observed heterogeneity in growth and employment. But failed to consider the relationship between policy shocks and the type of unemployment. 
Zavodny and Zha (2000) scrutinised the relationship between monetary policy and the race-specific unemployment rates in the US. They found that the black unemployment rate does respond slightly differently than the overall unemployment rate to macroeconomic variable shocks. Carlino and DeFina (1998) study the possibility that the monetary policy has different effects across regions in the US since the timing and the magnitude of cycles in economic activity vary across regions. They concluded that different regions are affected differently by monetary policy. Algan (2002) found that a positive demand shock decreases the unemployment rate permanently in France and USA.

Berument et al (2008) investigated how macroeconomic policy shocks in Turkey affect the total unemployment and provides evidence on the differential responses of the unemployment by sectors of economic activity. The study made two remarkable contributions to knowledge. First, it considered not only the response of total unemployment but also the response of unemployment by sectors of economic activity. Second, it considered not only the effect of monetary policy shocks, but also the effects of several other macroeconomic shocks. Quarterly data that covered the period 1988:01 to 2004:04 was used. A VAR model with a recursive order was employed to estimate the effects of shocks in real GDP, price, exchange rate, interbank interest rate, money supply and own sectoral unemployment on unemployment by sectors of economic activity. The results of the study indicated that positive income shock is followed by a decrease in unemployment in all economic activity groups during the initial periods except the unemployment in the Electricity sector and the Community Services sector. The study, therefore, concluded that unemployment in different sectors of economic activity respond differently to various macroeconomic policy shocks.

Zawojska (2010) focused on overall unemployment in Poland and went ahead to highlight the agriculture connections with the national economy and particularly with labour market that might govern individual choices between employment in the farm and non-farm sectors. The study aimed first to complement the literature on unemployment in Poland, and second to examine the relationship between macroeconomic indicators and unemployment rate. It consisted of two major parts. The first part presented an overview of the relevant literature concerning the above-mentioned relations. The next part, laid out the results of the study. Correlation analysis and simple linear models were applied to explain the relationship of unemployment rate with individual macroeconomic indicators. The results showed that during the years included in this study (2002-2008), unemployment rate in Poland was statistically significant and negatively impacted by the economic growth, Gross Domestic Product per capita, exports and imports, foreign direct investments, final consumption expenditures, gross capital formation, and central government expenditures. At the same time, the real interest rates of the central bank were positively related to the unemployment rate. No statistically significant linear relationship was found between the current and past unemployment rates in Poland.

Dogan (2012) investigated the response of unemployment to selective macroeconomics shocks for the period of 2000: Q1-2010:Q1. He found that positive shocks to growth, growth in export and inflation reduced unemployment. On the other hand, shocks to exchange rate, interbank interest rate and money supply increased unemployment. The results, according to the author, were consistent with Phillips curve and Okun's Law suggestion. Namely, negative relationship between output and unemployment and positive relationship between unemployment and inflation were found.

The Bankole and Fatai (2013) estimated the Okun's coefficient, and checked the validity of Okun's law in Nigeria, using the time series annual data that spanned the period 1980 to 2008. The Engle granger co-integration test and Fully Modified OLS were employed. The empirical evidence from the study showed that there is positive coefficient in the regression, implying that Okun's law interpretation is not applicable to Nigeria. They, thus, recommended that government and policy makers should adopt economic policies that are more oriented to structural changes and reform in labour market.

\subsection{Theoretical framework and methodology}

\subsection{Theoretical framework}

A number of studies (Cascio, 2001; Orphanides and Williams, 2002; Djivre and Ribon, 2003; Berument et al, 2008; Bankole and Fatai, 2013; among others) have examined the relationship between Unemployment and other macroeconomic variables. In this study, we re-examined the Okun's law for Nigeria, using the vector error correction model (VECM). The model has the capacity to produce parameters that are consistent with theory and of good fit. Unlike most existing studies, Bankole and Fatai, 2013 inclusive, the present study carried out several diagnostic tests of model adequacy to check how "good" the fitted model is and gauge the error process of the would-be determinants of unemployment in Nigeria. 


\subsection{Methodology}

The model presents unemployment rate as the dependent variable and introduces some selected macroeconomic variables as explanatory variables that attempt to capture the variations in unemployment rate in Nigerian economy. The model is expressed as:

$\mathrm{UNER}=\mathrm{f}\left(\mathrm{UNER} \mathrm{t}_{\mathrm{t}-1}, \mathrm{INF}, \mathrm{RGDP}, \mathrm{M} 2, \mathrm{EXR}, \mathrm{LR}, \mathrm{GEX}, \mathrm{OPEN}\right)$

Where, UNER $=$ unemployment rate, $\mathrm{UNER}_{\mathrm{t}-1}=$ is the immediate past value of unemployment rate, INF $=$ Inflation Rate, RGDP = Real Gross Domestic Product, M2 = Money Supply, EXR= Exchange Rate, LR = Lending Rate, GEX = Government Expenditure, and OPEN = Openness of the economy. The parameterized version of equation the unemployment model is presented as follows:

$U N E R_{t}=\lambda_{0}+\lambda_{1} U N E R_{t-1}+\lambda_{2} I N F_{t}+\lambda_{3} R G D P_{t}+\lambda_{4} M 2_{t}+\lambda_{5} E X R_{t}+\lambda_{6} L R_{t}+\lambda_{7} G E X_{t}+\lambda_{8} O P E N_{t}+\varepsilon_{1 t}$

\subsection{Estimation technique}

Time series data are often assumed to be non-stationary and thus, it is necessary to perform unit root test to ensure that there is stationarity of data. The test would be employed to avoid the problem of spurious regression. In conducting this test, the Augmented Dickey-Fuller (ADF) and the Philip-Perron (PP) unit root tests would be employed to determine the stationarity of data. The ADF approach addresses the serial correlation of the first differences of a series in a parametric fashion by estimating additional nuisance parameters whereas the PP test follows non-parametric statistical methods to account for the autocorrelation in the error terms without adding lagged difference terms (Gujarati, 2009).The decision rule is that Augmented Dickey-Fuller (ADF) and Philip-Perron tests statistics must be greater than Mackinnon Critical Value at either $1 \%, 5 \%$, or $10 \%$ and at absolute term i.e. ignoring the negative sign of the ADF and PP tests statistics and Mackinnon critical value, before the variable can be adjudged to be stationary.

We proceed to test for co-integration among the variables. The concept of co-integration is relevant to the problem of determination of long-run equilibrium relationship. Co-integration is the statistical implication of the existence of a long-run equilibrium relationship between variables. The condition for a long run co-integrating vector is that the trace statistics (likelihood ratio) must be greater than $5 \%$ critical value. According to Granger (1986), a test for cointegration can be believed to be a pre-test to avoid 'spurious regression' situations. In this study, we adopt the Johansen and Juselius (1990,1992, and 1994) approach for cointegration test because of its advantages over the Engle Granger static procedure.

Next, we specify the short-run dynamic equation. The existence of cointegration necessitates the construction of error correction model in order to model dynamic relationships. The error correction mechanism is the speed or degree of adjustment from the short run equilibrium to the long run equilibrium state. Precisely, it shows the rate at which unemployment rate adjusts to changes in the explanatory variables. Therefore, the greater the coefficient of the parameter, the higher the speed of adjustment of the model from short run to the long run and vice-versa. The result of the ECM is specified in an over parameterized form. However, the parsimonious encompassing model depicts the best fitted result for the dynamic specifications. The acceptable rule is that the coefficient of the ECM term must be negatively signed and significant to ensure convergence of the dynamics to the long-run equilibrium.

Finally, we carry out several diagnostic tests of model adequacy. Specifically, we adopt the Jarque-Bera (JB) Test of Normality, the Breusch-Godfrey (BG) test for serial correlation, White heteroskedasticity and Ramsey Reset Test.

\subsection{Empirical analysis}

\subsection{Unit roots results}

The results of the ADF and the PP tests of stationarity are reported in Table 5.1. All the variables (UNER, INF, RGDP, M2, EXR, LR, GEX and OPEN) were stationary at first difference. This is because their respective ADF and $\mathrm{PP}$ tests statistics value is greater than Mackinnon critical value at $1 \%(5 \%)$ and at absolute term after first difference. The results of two techniques reveal that all the variables are integrated of order one, I(1). Thus, the null hypothesis of non-stationarity is rejected at both $1 \%$ and $5 \%$ levels of significance. 


\subsection{Johansen cointegration test results}

Table 5.2 presents the results of the Johansen cointegration test. Lag length of three (3) was selected as suggested by FPE, AIC and HQ. The results show that long-run relationship or co-integration exists among unemployment rate (UNER), inflation rate (INF), real gross domestic product (RGDP), money supply (M2), exchange rate (EXR), lending rate (LR), government expenditure (GEX) and openness of the economy (OPEN). This is because the critical value at $5 \%$ is less than both trace statistic and maxi-eigen statistic. Therefore, the hypothesis of no co-integration has been rejected at $5 \%$ significance level. Thus, there is evidence of a long run relationship among the macroeconomic variables. Specifically, Trace test indicates three cointegrating equations at $5 \%$ critical level while Maxi-Eigen test indicates two cointegrating equations at $5 \%$ critical level. This implies that there is a stable long-run relationship among the eight macro-variables and so we can avoid both the spurious and inconsistent regression problems which otherwise would occur with regression of non-stationary data series.

Table 1: ADF and PP unit root results

\begin{tabular}{lrrrr}
\hline Variable & ADF Statistic & Order of Integration & PP Statistic & Order of Integration \\
\hline UNER & $-6.12^{* *}$ & $\mathrm{I}(1)$ & $-6.11^{* *}$ & $\mathrm{I}(1)$ \\
INF & $-6.75^{*}$ & $\mathrm{I}(1)$ & $-12.68^{*}$ & $\mathrm{I}(1)$ \\
RGDP & $-6.11^{* *}$ & $\mathrm{I}(1)$ & $-6.12^{* *}$ & $\mathrm{I}(1)$ \\
M2 & $-12.02^{*}$ & $\mathrm{I}(1)$ & $-14.64^{*}$ & $\mathrm{I}(1)$ \\
EXR & $-5.78^{*}$ & $\mathrm{I}(1)$ & $-5.77^{*}$ & $\mathrm{I}(1)$ \\
LR & $-10.42^{*}$ & $\mathrm{I}(1)$ & $-10.51^{*}$ & $\mathrm{I}(1)$ \\
GEX & $-7.63^{*}$ & $\mathrm{I}(1)$ & $-7.58^{*}$ & $\mathrm{I}(1)$ \\
OPEN & $-7.69^{*}$ & $\mathrm{I}(1)$ & $-7.63^{*}$ & $\mathrm{I}(1)$ \\
\hline
\end{tabular}

${ }^{* *}(*)$ denotes rejection of the null hypothesis at $1 \%(5 \%)$ significance level.

\subsection{Johansen cointegration test results}

Table 5.2 presents the results of the Johansen cointegration test. Lag length of three (3) was selected as suggested by FPE, AIC and HQ. The results show that long-run relationship or co-integration exists among unemployment rate (UNER), inflation rate (INF), real gross domestic product (RGDP), money supply (M2), exchange rate (EXR), lending rate (LR), government expenditure (GEX) and openness of the economy (OPEN). This is because the critical value at $5 \%$ is less than both trace statistic and maxi-eigen statistic. Therefore, the hypothesis of no co-integration has been rejected at $5 \%$ significance level. Thus, there is evidence of a long run relationship among the macroeconomic variables. Specifically, Trace test indicates three cointegrating equations at $5 \%$ critical level while Maxi-Eigen test indicates two cointegrating equations at $5 \%$ critical level. This implies that there is a stable long-run relationship among the eight macro-variables and so we can avoid both the spurious and inconsistent regression problems which otherwise would occur with regression of non-stationary data series.

Table 2: Johansen cointegration test results

\begin{tabular}{llrrrr}
\hline $\mathrm{H}_{0}$ & $\mathrm{H}_{1}$ & Trace Statistic & 0.05 Critical Value & Max-eigen Statistic & 0.05 Critical Value \\
\hline $\mathrm{r}=0$ & $\mathrm{r}>0$ & $611.99^{*}$ & 159.53 & $287.94^{*}$ & 52.36 \\
$\mathrm{r} \leq 1$ & $\mathrm{r}>1$ & $324.05^{*}$ & 125.61 & $134.02^{*}$ & 46.23 \\
$\mathrm{r} \leq 2$ & $\mathrm{r}>2$ & $190.03^{*}$ & 95.75 & 83.05 & 40.07 \\
$\mathrm{r} \leq 3$ & $\mathrm{r}>3$ & 106.98 & 69.81 & 40.45 & 33.87 \\
$\mathrm{r} \leq 4$ & $\mathrm{r}>4$ & 66.52 & 47.85 & 31.11 & 27.58 \\
$\mathrm{r} \leq 5$ & $\mathrm{r}>5$ & 35.41 & 29.79 & 20.53 & 21.13 \\
$\mathrm{r} \leq 6$ & $\mathrm{r}>6$ & 14.87 & 15.49 & 14.86 & 14.26 \\
$\mathrm{r} \leq 7$ & $\mathrm{r}>7$ & 0.00 & 3.84 & 0.00 & 3.84 \\
\hline
\end{tabular}

${ }^{*}$ denotes rejection of the null hypothesis $\left(\mathrm{H}_{0}\right)$ at $5 \%$ significance level. The Trace test indicates 3 cointegrating eqn $(\mathrm{s})$ at the 0.05 level while max-eigen value test indicates 2 cointegrating equations at $5 \%$ level.

\subsection{Vector error correction model}

Having established that the variables are stationary and integrated of order I(1) with a long run relationship, we then employed the vector error correction model (VECM) to capture the short run deviations that might have occurred in estimating the long run cointegration equation. The final parsimonious vector error correction model results are presented in table 5.3 below. The model which specifically assumed a linear trend and no intercept in the co-integrating equations was adopted based on data coherence, parameter consistency with theory, and goodness of fit. 
From table 5.3(below), RGDP made positive and significant impact on unemployment (UNER) at lag 2. Specifically, a $1 \%$ increase in RGDP at the second lag generates about $1.14 \%$ increase in unemployment. This result lends credence to the empirical findings of Dogan (2012) but contradicts Zawojska (2010). The result also reveals that current exchange rate (EXR) impacted positively and significantly on UNER whereas its impact at lag 2 was negative. Basically, a $1 \%$ increase in current EXR leads to a $0.15 \%$ increase in UNER while a $1 \%$ increase in EXR at the second lag period depresses UNER by $0.13 \%$. Government expenditure (GEX) positively affects UNER both at its current and second lag periods although it impacts are not significant.

Table 3: Parsimonious vector error correction model results

Dependent Variable: D(UNER)

Method: Least Squares

\begin{tabular}{lrcr}
\hline Variable & Coefficient & Std. Error & t-Statistic \\
\hline C & 0.033313 & 0.263759 & 0.126301 \\
D(UNER(-1)) & -0.186119 & 0.087298 & -2.131998 \\
D(LRGDP(-2)) & 1.148458 & 0.486337 & 2.361443 \\
D(LM2) & -1.411482 & 0.631282 & -2.235896 \\
D(EXR) & 0.159795 & 0.014445 & 11.06199 \\
D(EXR(-2)) & -0.067915 & 0.012691 & -5.351476 \\
D(LR) & -0.123149 & 0.049095 & -2.508380 \\
D(LR(-1)) & -0.133719 & 0.049456 & -2.703804 \\
D(LGEX) & 1.100684 & 0.763974 & 1.440735 \\
D(LGEX(-2)) & 0.790856 & 0.659686 & 1.198836 \\
D(OPEN(-1)) & -2.983301 & 2.014983 & -1.480559 \\
D(OPEN(-2)) & -4.076973 & 2.134180 & -1.910323 \\
ECM & -0.394427 & 0.112555 & 3.504302 \\
\hline R-square & 0.909952 & Mean dependent var & 0.511905 \\
Adjusted R-square & 0.872690 & Akaike info criterion & 2.960129 \\
S.E. of regression & 0.938746 & Durbin-Watson stat & 1.953533 \\
F-statistic & 24.42080 & Prob(F-statistic) & 0.000000 \\
\hline
\end{tabular}

As the result indicates, a $1 \%$ increase in GEX leads to $1.10 \%$ and $0.79 \%$ increases in UNER at current and second lag periods respectively. This result does not support a priori expectation as increase in government expenditure is expected to reduce unemployment. A possible reason for this contradictory result is that huge government spending goes into non-employment generating sectors/ventures and looting of public treasuries by corrupt public office holders which reflects in government account as economic spending. The results further indicate a negative and significant relationship between money supply (M2) at lag 2 and UNER; current lending rate (LR) and UNER; LR at lag 1 and UNER whereas openness (OPEN) of the economy at both first and second lag periods impacted negatively and insignificantly on UNER. It is evident from the result that previous UNER at lag 1 impacted negatively and significantly on current UNER within the period under study. The impact of M2 and OPEN of the economy on unemployment aligns with theoretical expectations as both are expected to dampen UNER.

A striking finding from the result is that inflation (INF) is not make it to the parsimonious result. Thus, suggesting that it does not determine UNER in Nigeria, at least in the short-run. This result deviates from empirical regularity as captured in the Philips curve. This empirical finding may be due to the fact that INF has become inherent in the Nigerian economy and UNER might have become immune to its shocks.

The coefficient of the error correction term which measures the speed of adjustment of UNER towards long-run equilibrium is well-behaved as it is negatively signed and significant at $5 \%$ level. This implies that the rate at which variation of UNER at time $t$, adjusts to the single long-run co-integrating relationship is different from zero. Specifically, the coefficient of the ECM revealed that the speed with which UNER adjusts the regressors is about 39\% in the short run. The coefficient of determination (R-squared) shows that about $90 \%$ of the variation in UNER is jointly explained by the explanatory variables in the model. Implicitly, the remaining $10 \%$ may be attributed to the stochastic variables. The overall model is significant as revealed by the F-statistic and its corresponding probabilistic value.

\subsection{Diagnostic test}

Having presented and analyzed the parsimonious vector error correction results, we further carried out several diagnostic tests of model adequacy to check how "good" the fitted model is. Specifically, we employed the Jarque-Bera (JB) Test of Normality, the Breusch-Godfrey (BG) test for serial correlation, White 
heteroskedasticity and the Ramsey Reset Test. The JB test of normality which is an large-sample (or asymptotic) test is based on the OLS residuals while the Breusch-Godfrey test, which is also known as the Lagrange Multiplier (LM) test, is used to test for autocorrelation. It has been generally adduced to be more robust in empirical diagnostic tests than the Durbin Watson test statistics because it is amenable to use for: (i) simple or higher-order moving averages of white noise error terms; (ii) non-stochastic regressors such as lagged values of the dependent variable and (iii) higher-order schemes. According to White (1980), White Heteroskedasticity Test is a test of heteroskedasticity in the residuals from a least square regression. OLS estimates are consistent in the presence of heteroskedasticity, but the conventional computed errors are no longer valid. White's test is a test of the null hypothesis of no heteroskedasticity against heteroskedasticity of some unknown general form. The Ramsey Reset Test is a general test of specification error. If the $F$ value is highly significant, it suggests that the initial model might have been wrongly specified.

Table 4: Summary of diagnostic tests for the model

\begin{tabular}{lr}
\hline Tests & Results \\
\hline Jarque-Bera Normality & $8.14(0.01)$ \\
Breusch-Godfrey (B-G) & $0.50(0.31)$ \\
Heteroskedasticity & $0.47(0.42)$ \\
Ramsey Reset & $0.01(0.00)$ \\
\hline
\end{tabular}

Source: Authors' computation using Eviews6

Note: The probability is given in parenthesis while figures outside the parenthesis are the F-statistics.

The outcome of the diagnostic tests as reported in Table 5.4 is satisfactory. Under the null hypothesis that the residuals are normally distributed, the JB test for residual normality assumption is not violated. The table also shows that the error process could be described as normal for the determinants. The B-G test which is noted to have stronger statistical power revealed the absence of autocorrelation. Also, the absence of white heteroskedasticity and specification error was indicated. The results of the tests suggest that the model is well specified, and hence the obtained empirical results are plausible.

\subsection{Conclusion and recommendation}

This paper empirically examined the effects of selected macroeconomic variables on unemployment rate in Nigeria. Review of related literature was robust. The unit root tests results using ADF and the PP test of stationary implicated all the variables as being integrated of order one, I(1). The Johansen cointegration test results revealed a long run relationship among the chosen variables which necessitated the use of the Vector Error Correction Model (VECM). The results revealed that while RGDP at lag 2 and current EXR positively and significantly affect UNER within the period under study whereas UNER at lag 1, M2 at lag 2, EXR at lag 2, current LR and its first lag negatively and significantly affected it. Current GEX and its lag 2 positively and insignificantly influenced UNER while OPEN at lags 1 and 2 negatively and insignificantly affected unemployment. The outcome of all the diagnostic tests validates the acceptability of the model's results as plausible.

Based on our empirical findings, we recommend as follows. First, the corrupt government officials should abstain from looting of public treasuries and channel spending to greater employment sectors/ventures. Second, the government should keep tab on the variables implicated by the model of this study as significant determinants of unemployment in Nigeria to ensure that they move in the desired direction with a view to alleviating unemployment and its associated menace.

\section{References}

Agenor Pierre R. and J. Aizenman, (1999). Macroeconomic Adjustment with Segmented Labor Markets, Journal of Development Economics, 58, 277-296.

Alexius A. and B. Holmlund, (2007). Monetary Policy and Swedish Unemployment Fluctuations. IZA Discussion Paper, No. 2933, Bonn.

Algan, Yann (2002). How Well Does the Aggregate Demand-Aggregate Supply Framework Explain Unemployment Fluctuations? A France-United States Comparison. Economic Modelling, 19, 153-177.

Asaju K., Arome S. and Anyio F. (2014). The rising rate of unemployment in Nigeria: the socio-economic and political implications, Global business and Economic Research, Vol. 3, No 2.

Bankole A. S. and Fatai B. O. (2013). Empirical Test of Okun's Law in Nigeria, International Journal of Economic Practices and Theories, Vol. 3, No. 3.

Berument H., Dogan N. and Tansel A. (2008). Macroeconomic Policy and Unemployment by Economic Activity: Evidence from Turkey, Economic Research Center, Middle East Technical University, Ankara, Turkey. 
Bisping T. and H. Patron, (2005). Output Shocks and Unemployment: New Evidence on Regional Disparities, International Journal of Applied Economics, 2(1), 79-89.

Blackley, P.R., (1991). The Measurement and Determination of State Equilibrium Unemployment Rates, Journal of Macroeconomics, 13(4), 641-656.

Carlino, G and R. DeFina, (1998). The Different Regional Effects of Monetary Shocks. The Review of Economics and Statistics, 80(4), 572-587.

Cascio Lo I., (2001). Do Labor Markets Really Matter? University of Essex, Department of Economics, Colchester, Essex.

CBN (2014). Statistical Bulletin, Central Bank of Nigeria, Abuja, Nigeria.

Djivre J. and S. Ribon, (2003). Inflation, Unemployment, the Exchange Rate, and Monetary Policy in Israel, 1990 99: a SVAR Approach, Israel Economic Review, 2, 71-99.

Doğan T. (2010). Macroeconomic Variables and Unemployment: The Case of Turkey. International Journal of Economics and Financial Issues, Vol. 2, No. 1, 2012, pp.71-78.

EconomyWatch. (2010). Nigeria Unemployment, Retrieved fromhttp://www.economywatch.com/unemployment/countries/nigeria.html on 21/11/14.

Ewing B. T., W. Levernier and F. Malik, (2002). The Differential Effects of Output Shocks on Unemployment Rates by Race and Gender, Southern Economic Journal, 68(3), 584-599.

Freeman D. G., (2000). Regional Tests of Okun's Law, International Advances in Economic Research, 6(3), 557570.

Izraeli O. and K. J. Murphy, (2003). The Effect of Industrial Diversity on State Unemployment Rate and Per Capita Income, The Annals of Regional Science, 37(1), 1-14.

Lynch G.J. and T. Hyclak, (1984). Cyclical and Noncyclical Unemployment Differences among Demographic Groups, Growth and Change, 15(1), 9-17.

Okun, A. (1962). Potential GNP: Its measurement and significance. In American Statistical Association, Proceedings of the Business and Economic Statistics Section (pp. 98-104).

Orphanides A. and J. C. Williams, (2002). Robust monetary policy rules with unknown natural rates", Board of Governors of the Federal Reserve System, Finance and Economics Discussion Series: 2003-11, US.

Paci R., F. Pigliaru and M. Pugno, (2001). Disparities in Economic Growth and Unemployment across the European Regions: A Sectoral Perspective, North South Economic Research, Working Paper CRENOS: 200103, University of Cagliari and Sassari, Sardinia.

Perman, R., and Tavera, C. (2007). Testing for convergence of the Okun's law coefficient in Europe. Empirica, 34(1), 45-61.

Ravn, M and S Simonelli, (2006). Labor Market Dynamics and the Business Cycle: Structural Evidence for the United States, Center for Studies in Economics and Finance, Working Paper, no 182.

The Sun Newspaper. (2014). Nigeria's grim unemployment statistics, Retrieved from http://sunnewsonline.com/new/?p=59179 on 24th November, 2014.

Zavodny M. and T. Zha, (2000). Monetary Policy and Racial Unemployment Rates, Federal Reserve Bank of Atlanta, Economic Review, 85(4), 1-16.

Zavodny M. and T. Zha, (2000). Monetary Policy and Racial Unemployment Rates, Federal

Zawojska A. (2010). Effect of Macroeconomic Variables on Unemployment Rate in Poland, Economic Science for Rural Development Conference Proceedings; Issue 22, p48. 